\title{
The Umbilical Cord Gag in Luis Buñuel's Subida al cielo (1951)
}

\author{
JO EVANS \& BREIXO VIEJO \\ University College London
}

\section{Key words: Amour fou, Cinephilia, Freud, Kracauer, Luis Buñuel, Mariolotry, Surrealism}

'J'ai un côté entomologiste. L'examen de la réalité m'intéresse beaucoup.'

'De una sola ventana tan alta como los ojos de la madre cuando se inclinan sobre la cuna. Cerca de la ventana pende un ahorcado que se balancea sobre el abismo cercado de eternidad, aullado de espacio. SOY YO. Es mi esqueleto del que ya no quedan más que los ojos. ${ }^{2}$

Luis Buñuel is well-known for his sacriligious attachment to the Virgin Mary. She makes a memorable appearance in the La Voie lactée (1969), and his son, Juan Luis, confirms this anecdotally in his memoirs when he mentions the icon of the Virgin Mary that friends provided for his father's study. ${ }^{3}$ Buñuel is also well-known for surreal dream sequences in which his protagonists are tethered (symbolically or otherwise) to their parents. Most famously, Un Chien andalou (1929) features the chastizing paternal double of a protagonist who cannot reach the woman of his dreams because he is tethered to donkey corpses, grand pianos and Marist priests. Young Pedro's dream sequence in Los olvidados (1950) features his mother and his nemesis, El Jaibo. This mariolotrous dream-mother is associated with food, although, unlike the apple peel that is so crucial to the umbilical cord gag in Subida al cielo (1951), Pedro's mother holds out a lump of uncooked meat. Then there is the disapproving dream-father in Robinson Crusoe (1953), who is not so much a double as an

\footnotetext{
${ }^{1}$ Luis Buñuel in André Bazin and Jacques Doniol-Valcroze, 'Entretien avec Luis Buñuel', Cahiers du Cinéma 36 (June 1954), 2-14 (p. 8).

2 This quotation is from the prose poem 'Mojigatería' Buñuel sent in a letter to José Bello in January 1929, quoted in Agustín Sánchez Vidal, Buñuel, Lorca, Dalí: El enigma sin fin (Barcelona: Planeta, 1988), 184, and published under the title 'Palacio de hielo' in Helix, Vilafranca del Penedès, no. 4 (May 1929), 5.

${ }^{3}$ Juan Luis Buñuel, Good Films, Cheap Wine, Few Friends: A Memoir, ed. and with an intro. by Linda C. Ehrlich (Shaker Heights: Shika Press, 2014), 213.
} 
opposite, appearing to the malnourished Robinson in the guise of a scolding Father Christmas-like figure). ${ }^{4}$ These dream sequences demonstrate the importance of the parental 'ties that bind' to Buñuel's visual gags and, in particular, to the one in Subida al cielo that we examine here by way of the two quotations cited in the epigraph.

In the first of these, Buñuel describes himself as something of an entomologist, interested in the scientific examination of reality. It is taken from an interview he gave in 1954, and is a useful reminder of the curiosity for scientific that lies behind the (admittedly unscientific) umbilical cord gag in Subida al cielo. The second is of more central interest to this paper. This quotation dates back to the late 1920s and is from a prose poem Buñuel sent to his close friend from the Madrid 'Resi' days, José (Pepín) Bello. It is a graphic reminder of Buñuel's interest in surrealism, and this maternally associated, skeletal Buñuel (with only the eyes still intact) has an interesting relationship to his film career. Taken together, these quotations convey the fascination with the external and internal worlds that drives the black humour in Buñuel's work. This internal/external curiosity has produced a legacy of visual gags that may be traced back to the Spanish esperpento and interpreted via Freud by way of de Sade. Usually funny, often shocking, and frequently scatalogical, the visual gag was vital to Buñuel's film career from the outset. A year or so after writing the letter to Pepín Bello that we shall return to below, Buñuel sent a letter to Marie Laure and Charles de Noailles, the wealthy patrons of L'Âge d'or (1930). In it he tells them the film is nearly finished and that it contains some new 'gags' he cannot adequately convey in writing: 'Le decoupage a été un peu changé avec de nouveaux gags que $j$ 'ai trouvé et que je regrette ne pas pouvoir vous racontér par ecrit parceque je n'arriverai pas a le faire comme il faut. ${ }^{5}$ This letter indicates that the use of the word 'gag', in English, to describe what would become the defining trait of Buñuel's career predates his first trip to Hollywood in October 1930; a working visit that would remove him from Paris throughout the drama that would accompany the release of the film in question.

Although the more commercially-minded 'Buñuel' tends to be associated with the Mexican 'películas alimenticias' (including Subida al cielo), the need to make commerically viable films had been a preoccupation from $L^{\prime} \hat{A} g e$ d'or onwards. ${ }^{6}$ Buñuel kept a keen eye on the budget, and he had anticipated L'Âge d'or would be released more widely and more

\footnotetext{
${ }^{4}$ For information dating Robinson Crusoe to 1953 see Javier Herrera Navarro, Luis Buñuel en su archivo: de Los olvidados a Viridiana (Madrid: Fondo de Cultura Económica, 2015), 172.

${ }^{5}$ Dated 8 February 1930 and published in Jean-Michel Bouhours and Nathalie Schoeller, L'Âge d'or. Correspondance Luis Buñuel - Charles de Noailles. Lettres et documents (1929-1976) (Paris: Les Cahiers du Musée National d'Art Moderne, Hors-série/Archives, 1993), 46.

${ }^{6}$ For discussion of the link between the 'películas alimenticias' and Buñuel's more overtly 'auterist' films see Peter Evans, The Films of Buñuel: Subjectivity and Desire (Oxford: Oxford University Press, 1995), 38, and Geoffrey Kantaris, 'The Cinematic Labor of Affect: Urbanity and Sentimental Education in El bruto and Ensayo de un crimen' in Rob Stone and Julián Gutiérrez-Albilla, A Companion to Luis Buñuel. Chichester: Wiley-Blackwell, 2013), 302-323 (p. 302)
} 
commercially than Un Chien andalou. So the outcry it caused and ban on its commercial release were a financial blow. Even at this early stage, Buñuel was acutely aware of the need to balance aesthetic concerns with financial return, and he sought the de Noailles' blessing, in a letter dated 5 December 1931 to make a more commercially viable short version of the film to be funded by Braunberger. ${ }^{7}$ This was also turned down by censors and, as far as we know, no copies survive. ${ }^{8}$ This proposal, however, anticipates the commercial direction his career would take in Mexico and, amongst the numerous films he would direct there, Subida al cielo is a fine example of the techniques Buñuel would develop to combine surrealist desire with financial demand after this rocky start. This paper focuses on the umbilical cord dream sequence in this film to illustrate the role played in Buñuel's legacy by this attachment to the mother and mariolotry; the importance to his work of Freud, Surrealism and amour fou; and his ironic appreciation of cinephilia.

Subida al cielo is based on the honeymoon experiences of a friend of Buñuel's, the exiled Spanish poet Manuel Altolaguirre. Altolaguirre produced and provided the source material, funding was provided by his wealthy Cuban wife, María Luisa Gómez Mena, and the film was co-written by Buñuel, Juan de la Cabada and Lilia Solano. ${ }^{9}$ It was released during the prolific phase that followed Bunuel's 'Best Director' award at the Cannes film festival for Los olvidados in 1951. Between 1950 and 1951, he directed five films: Los olvidados, Susana (1950), La hija del engaño (1951), Una mujer sin amor (1951), and Subida al cielo. Subida al cielo was chosen as Mexico's official selection for the Cannes film festival in 1952 and it won the Critics' Prize, framing this remarkable year with two prizes at Cannes for films whose diegesis revolves, if in very different ways, around the fate of children.

The plot is loosely tied to three events: a wedding, a mother's illness, and the sudden need to ensure her deathbed wish is legally binding. The action is motivated by the greed of two elder sons, who plan to cheat their nephew Chucho out of his inheritance. ${ }^{10}$ The story is introduced by a conventional narrative voiceover that sets the scene for this light comedy in a

\footnotetext{
${ }^{7}$ Bouhours and Schoeller, L'Âge d'or. Correspondance..., p. 149.

${ }^{8}$ Román Gubern and Paul Hammond, Luis Buñuel: The Red Years, 1929-1939 (Madison: The

University of Winsconsin Press), 98.

${ }^{9}$ For this and further background information on Subida al cielo see: http://cinemexicano.mty.itesm.mx/peliculas/subida_cielo.html (accessed 25 November 2016); Herrera Navarro, Luis Buñuel en su archivo..., 145-164; and Manuel Fructuoso's always fascinating blog site 'En torno a Buñuel: https://lbunuel.blogspot.co.uk/2014/06/subida-al-cielo-1951.html (accessed 28 November 2016).

${ }^{10}$ The sons are Felipe (Víctor Pérez) and Juan (Roberto Cobo, who played Jaibo in Los olvidados).
} 
small village in the state of Guerrero that (the voiceover tells us) we 'might as well call San Jerónimo'. The voice-over also explains that the inhabitants own their own coconut trees and are independently wealthy; that the village has no church, so the villagers are untainted by religious indoctrination; and that couples celebrate their wedding vows by taking a boat to a deserted island, after making a formal visit to the wife's parental home where the groom begs his mother-in-law for forgiveness. Having set the scene for a plot involving guilt (the need for forgiveness), money, and an imminent sexual encounter involving a newly married couple, Oliverio (Esteban Márquez) and Albina (Carmen González), the boat trip to the nuptial island is interrupted when Oliverio's mother doña Ester (Paz Villegas) is taken ill and his brother, Felipe, comes to fetch him home. This intervention allows for a sequence in which newly married Albina is towed back to the village alone in a boat behind the one in which the two brothers are now squabbling, a comic scenario that prefigures the visual link between frustration, women and water that returns in Oliverio's dream. As a result of the elder brothers' conniving, good son, Oliverio will have to take a bus to town, Petatlán, where a lawyer will draw up papers to secure his mother's legacy in favour of Chucho, the young son of a sister who died in childbirth.

On this bus, Oliverio will encounter a blond temptress, Raquel (Lilia Prado), whose centrality to this conventional comic narrative is indicated by an edit linking her bodily curves directly to the tortuous bends in the road on this 'Mexican Bus Ride' (to use the film's English title). ${ }^{11}$ Her body will also inspire the umbilical cord dream-gag we examine here.

\section{INSERT FIG 1: The Umbilical Cord Gag}

Raquel's body is as central to narrative desire, as children and mothers are to narrative momentum. There are children on the bus, described (sleeping) by their grandmother as 'angelitos, lo que es la inocencia', and a number of the delays that occur involve children. A woman will go into labour and bring the bus to a halt barely outside San Jerónimo. The bus driver, Silvestre (Luis Aceves Castañeda), will stop to attend extended birthday celebrations for his mother, Doña Sexta (Paula Rendón): a delay that means Oliverio will drive the bus alone, but for the tempting Raquel, to its erotic climax at the 'Subida del cielo'. Then there is a final delay when the bus stops to pick up the coffin of Silvestre's god-daughter, Eusebita (Silvia Castro). Despite the interruptions caused by the birth, birthdays and deaths of mothers and children, Oliverio will arrive home in time to forge his (now dead) mother's thumbprint on the will, and all ends well.

\footnotetext{
${ }^{11}$ Lilia Prado (1928-2006) also appeared in Abismos de pasión (Buñuel, 1954) and La ilusión viaja en tranvía (Buñuel, 1954).
} 
From this brief plot summary it is clear that the relationship between mothers and children is as important to this narrative as Raquel. Hence the hilarious three-minute dream sequence that we now analyse in more detail. It starts just over thirty-two minutes into this eighty-five minute film. Oliverio and Raquel are sitting at front of bus. Raquel, in the familiar Buñuelian guise of secular Eve, dangles her apple peel provocatively in front of Oliverio, but a young girl appears between them and snatches it away. ${ }^{12}$ Raquel then offers Oliverio the apple. He bites, looks directly at the camera, and a zoom blurs his dazed expression as we move into the dream sequence. Oliverio and Raquel are now alone on a bus that is magically driving itself. Raquel turns her back provocatively to Oliverio, inviting him to unzip her top. She then strips to the bathing suit that was, and is so useful to publicity stills. However, the comic excess in this screened fantasy also functions as a wry nod to the objectification of film starlets and the selling of sex onscreen. Raquel struts down the aisle of the bus that is now edged with tropical plants (conflating the bus with the paradisal island, on which Oliverio should now be consummating his marriage with his wife, perhaps). She sits and beckons to Oliverio as an abrupt edit moves to a shot of Albina, Oliverio's wife, rising like a composite Venus/Virgin Mary, from a river. Albina is drenched and looks put out, as if thoroughly taken aback by this unceremonious dunking.

As we cut, equally abruptly, back to the bus, Oliverio is crawling down the aisle to kiss Raquel's bare shoulder. There is now a random cut to a four-piece brass band preparing to play the cheerful film theme tune that will accompany this oediapally challenged fantasy. The focus returns to the illicit couple. Oliverio kisses Raquel. Action returns abruptly to the riverside. Oliverio is running along the river's edge (left to right) pursued by a woman wearing in the same drenched bridal/Virgin Mary gown as Albina, but this is Raquel. ${ }^{13}$ As she goes to kiss Oliverio, he pushes her in the river, conflating the objectification of these two (both now drenched) dream-women. Action cuts abruptly back to Oliverio and Raquel kissing on the bus. Oliverio pulls back to discover, stuck to his mouth, an extraordinarily wide and long piece of apple peel. Raquel takes a small bite out of this as Oliverio looks upwards offscreen left towards his mother, looking benignly down from a pillar.

\section{INSERT FIG 2: Apple-peeling Mother}

\footnotetext{
${ }^{12}$ This brief appearance of the girl foreshadows the role of Rita in Viridiana (1961).

${ }^{13}$ The links between Buñuel and Germaine Dulac are not often highlighted, although Gibson proposes Dulac as an influence on Un Chien andalou in Luis Buñuel: La forja de un cineasta (Madrid: Aguilar, 2013), 346. Similarly, this sequence echoes (consciously or not) the riverside chase in Dulac's $L a$ Coquille et le clergyman (1928), a film now often cited alongside Un Chien andalou as a foundational surrealist film text.
} 
She is peeling the apple that is attached to Oliverio. ${ }^{14}$ Oliverio smiles up at her. There is an abrupt cut to the brass band, then back to Oliverio, still gazing up at his mother. Back on the bus, Raquel is combing her hair. Shaking his head and gesturing negatively with his hand, as if to indicate their romance is over, Oliverio takes over the combing in a maternal gesture that Raquel responds to sensuously. A cutaway to the mother shows her still looking fondly down on the couple, peeling the apple that weaves Oliverio's fate. She winks, and the kissing couple stretch out on the floor of bus. Sheep appear from nowhere and run over the couple in the aisle of the bus. Cutting to the riverside, Albina, her wet gown now almost transparent, is surrounded by sheep (and goats). Oliverio appears left, and hugs Albina passionately. The brass band plays and a man walks by with a black sleep over his shoulder (between the kissing couple and the band). Albina now turns back into Raquel, who sticks her tongue out at Oliverio and laughs. An abrupt cut takes us to a medium shot of a woman's back rising from the river. Like Albina at the beginning, this woman also pushes her wet hair back from her eyes, but it is Raquel. She winks and raises an eyebrow, as a dissolve takes us back to Oliverio waking up on the bus, with a sheep on his lap.

This hilarious dream sequence, with its umbilical cord-apple peel and composite female objects of desire is not so much Spanish Esperpento by way Freud and de Sade as The Interpretation of Dreams by way of the Ealing Comedy Studios. And, although Buñuel wanted more sheep on the bus, it is a near-perfect joke on the oedipal layers that bind our perception and our desires, and that tether the Surrealist fantasy of amour fou so firmly to the 'rock' of bourgeois convention. At the same time, this sequence is a near-perfect parody of the cinematic fixation with the female star that had so irritated the younger Buñuel on his first visit to Hollywood in $1930 .{ }^{15}$ Lilia Prado, 'la Marilyn Monroe Mexicana', would go on to appear in over hundred films, three of them directed by Buñuel, and this still of her on the Subida al cielo bus shows how successfully she incarnates the projection, and our consumption of the screen goddess that Buñuel mocks in Oliverio's dream.

INSERT FIG 3: Lilia Prado, 'la Marilyn Monroe Mexicana'

Prado's body and the umbilical cord-apple peel fulfill a metacinematic function that highlights the complexity of our relationship with the screen, and the complexity of the relationship between that screen and the viewer's individual memories and experience. Kracauer use the same metaphor —of the umbilical cord — to illustrate the link between the

\footnotetext{
${ }^{14}$ This gag anticipates the one in reverse in Simón del desierto (1965) where Simón is on the pillar, his mother is on the ground, and the Lilia Prado role is played by Sivia Pinal as the devil.

${ }^{15}$ See Buñuel's letter to the de Noailles, 2 Decembre 1930, in Bouhours and Schoeller, $L$ 'A $\hat{A g e}$ d'or.

Correspondance..., 90-91.
} 
filmic and protofilmic object (in this case, the bodies of 'Raquel' and Lilia Prado), and the link between the screen image and screen viewer. ${ }^{16}$ For Kracauer, our response to the diegetic reality projected on screen produces an enhanced perception 'which is still intimately connected, as if by an umbilical cord, with the material phenomena from which its emotional and intellectual contents emerge. ${ }^{17}$ That is, Raquel's body retains its connection with Prado's, whilst at the same time this connection is enhanced (as we see so humorously in Oliverio's response) by the 'umbilical' connection her screened body has with the conscious and unconscious memories of the spectator. It is this, the simultaneously oedipal and generative/maternal role played by the spectator's body in the generation of meaning on screen - the spectator's 'umbilical' relationship to the diegetic world - that Buñuel uncovers so effectively when he 'tethers' Olivero's perception of the dreamy Raquel to his mother and Albina.

It is time to turn from the eruption of this dream sequence into the otherwise conventional narrative of Subida al cielo back to the skeleton of Buñuel we left dangling earlier (the director of the apple-peel-umbilical cord gag would surely forgive such a terrible pun?). In the letter Buñuel sent to Pepín Bello, he says he is about to go and spend time in Figueres working with Dalí on some 'ideas comunes y muy cinematográficas'. ${ }^{18}$ These ideas would, of course, result in the enormously successful, Un Chien andalou, the film that would seal Buñuel's move into directing, rather than a writing. However, at this stage, it is the imminent publication of the book and the fact that Pepín will be one of the dedicees that seem to preoccupy Buñuel. The book, Polismos did not appear, and by the time he is writing to Pepín, Buñuel had been working on it for a number of years. Although he admits in another letter that some of the images it contains may now be slightly 'démodés', he seems to think it will be the start of a great writing career: 'Esto es para romper el fuego. Luego voy a publicar cosas gordas'. ${ }^{19}$ He was wrong about the writing career, and it is not too much of a stretch, with the benefit hindsight and some rather agile lateral imagination, to see in the poetic image of the rolling eyes of Buñuel that end up in the 'charcos' of this poem, a sign of his imminent move from poetry to cinema. 'Mojigatería ${ }^{120}$ may not have secured Buñuel's career as a poet,

\footnotetext{
${ }^{16}$ Grateful thanks are due to Julián Gutiérrez Albilla for pointing out this 'umbilical' link with Kracauer.

${ }^{17}$ Siegfried Kracauer, Theory of Film: the Redemption of Physical Reality (Princeton, NJ: Princeton University Press, 1997), p. 71.

${ }^{18}$ Sánchez Vidal, Buñuel, Lorca, Dalí: El enigma..., p. 184.

1910 February 1929, Sánchez Vidal, Buñuel, Lorca, Dalí: El enigma ..., p. 190.

${ }^{20} \mathrm{We}$ are using the title Buñuel gives this prose poem in the letter to Bello rather than the title under which it was eventually published, because 'mojiatería' (which translates rather wonderfully into English as 'prudishness' or even 'holier-than-thou-ness') seems more evocative, and more appropriate to the content perhaps, than 'Palacio de hielo'.
} 
but it definitely contains the thematic seeds of the cinematic 'cosas gordas' he would go on to produce, and of the female archetypes that would return in them. ${ }^{21}$

Much has been written about the symbolism of eyes for the surrealists and much has also been written about the affective relationship between Buñuel and his mother. ${ }^{22}$ This, the link between a child and its mother's eye, is a perceptual relationship of seeing and being seen (of looking and recognition) that is echoed in the first line of the memoirs Buñuel would write with Jean-Claude Carrière. My Last Breath begins: 'During the last 10 years of her life, my mother gradually lost her memory' ${ }^{23}$ Buñuel goes on to say that, towards the end, although his mother was always glad to see him, she had no idea who he was. The reason Buñuel starts his memoirs with this anecdote (or, at least, the reason he gives) is that as his own memory is also beginning to fail him, he has begun to wonder if he is 'going to disappear altogether?'. ${ }^{24}$ This preoccupation with who we are when we are no longer recognized or remembered, with our relationship to our mothers and the tenuousness of our 'essential' self was presumably what attracted Buñuel to Freud and the surrealists, and the notion that we are just temporary (dangling?), multiple selves in thrall to repressed desires is a constant theme in his work. So this poetic image from the late 1920s of Buñuel's skeleton ('del que ya no quedan más que los ojos') dangling from a height linked symbolically to the eyes of a mother is profoundly suggestive. In the poem, after this gruesome opening and before it comes to an end with the arrival of the bayonets of Napoleon's soldiers in Zaragoza, the Buñuel eyes (gouged from his skeleton by a different woman with polished nails) croak in 'charcos', like a cartoon image of perception as something possibly lewd (the toad-like croaking) that is reflected in sequential roadside puddles while our frame (body/skeleton) remains tethered (as in Oliverio's dream) to the foundational lost object that is, for psychoanalysis, the mother.

\section{Conclusion:}

The graphic imagery of 'Mojigatería' bears a striking resemblance to the umbilical cord gag in Subida al cielo, and although Buñuel may have regretted he didn't become a writer, his roving eye (with apologies for this second poem-related pun) and gift for the visual gag would stand him in good stead. ${ }^{25}$ Famously interested in insects, and less interested in

\footnotetext{
${ }^{21}$ In addition to the symbolic mother, a nurse describes the fate of the eyes (bayonetted by Napoleon's soldiers) foreshadowing the story-telling governess in Ensayo de un crimen (1955), and the woman with polished nails, who plucks out the eyes foreshadows the numerous Belles dames sans merci who recur in Buñuel's films.

${ }^{22}$ For more on this poem with reference to the symbolic mother and the famous prologue of Un Chien andalou see Gibson, Luis Buñuel: La forja de un cineasta, 329 -330.

${ }^{23}$ Luis Buñuel, My Last Breath (London: Vintage, 1994), 3.

${ }^{24}$ Buñuel, My Last Breath, 4.

${ }^{25}$ For Buñuel's comment on his regrets: 'Hoy yo puedo tener alguna importancia como cineasta, pero hubiera dado todo gustoso a cambio de ser escritor. Es lo que realmente me hubiera gustado', see Agustín Sánchez Vidal, Luis Buñuel: Obra literaria (Zaragoza: Heraldo de Aragón, 1988) p. 18. In
} 
character motivation than guiding his actors' physical movements onscreen, ${ }^{26}$ Buñuel's entomological perspective may explain the physical detail of the umbilical cord/apple peel that makes this dream sequence so funny. It is also interesting to recall that, despite his reputation as the 'master' of surrealist filmmaking, like Hitchcock, Buñuel often applies Freud very literally to his narratives. ${ }^{27}$ In response, perhaps, to this kind of conscious and comical reference to Freud, Juan Luis laments in a letter to the editor of his own memoirs, Linda Ehrlich, that people take his father's films so seriously: 'It makes me really sad to see how solemn-looking and overcomplicated people get about him... He laughed while he was shooting. There were jokes, ironies... puns on the characters, the actors, the audience and, of course, on himself'. ${ }^{28}$ And while it is certainly vital to remember not to take Buñuel too seriously, it is easy to see why comic gags like this one provoke such on-going and intense theoretical debate. ${ }^{29}$ Lilia Pardo's body was, as we mentioned earlier, used not only to mimic the curves in the road and to feature in Oliverio's dream, but to function as cinephilic bait for viewers:

\section{INSERT FIG 4: publicity poster (1951) copyright Filmoteca Española (Madrid)}

So that, without losing any of its comic value, this vision of the oedipally challenged Oliverio functions effortlessly as a comic mise-en-abîme of our erotic and cinematic desires, and as a near-perfect illustration of what Cunningham defines evocatively elsewhere as the cinephile's 'longing to occupy/influence a space-time somewhere between the index and its referent' ${ }^{30}$ As Buñuel knows, it takes a lot of words to convey what this three minute sequence illustrates, and Oliverio's surreal erotic fantasy is a very succinct reflection of what sells on screen. This is a comic gag that has, therefore, as much relevance for the so-called

spite of these regrets, writing was always important to Buñuel's career. He worked closely with all of his co-scriptwriters, and eighteen of the thirty-two films he directed are literary adaptations: Gran casino (1947); El gran calavera (1949); La hija del engaño (1951); Una mujer sin amor (1951); Robinson Crusoe; Él (1953); Abismos de pasión (1954); El río y la muerte (1954); Ensayo de un crimen (1955); Cela s'appelle l'aurore (1955); La Mort en ce jardin (1956); Nazarín (1958); La Fievre monte a El Pao/Los ambiciosos (1959); The Young One/White Trash (1960); Journal d'une femme de chambre (1964); Belle de jour (1967); Tristana (1970); Cet obscur objet du désir (1977).

${ }^{26}$ Jean-Claude Carrière (co-script writer), Françoise Fabian (actor) and Pierre Lary (assistant director) discuss Buñuel's attention to the movement, rather than motivation, of characters. Interestingly, and with some qualification, Carrière links this to the surrealist focus on automatic writing, in 'A History of the Film', DVD extras, Belle de jour, 'The Luis Buñuel Collection' (Studio Canal, 1967), distributed by Studio Canal and Optimum World.

${ }^{27}$ For the (very) literal application of Freud by Hitchcock to plot development and characterization see Spellbound (1945), Psycho (1960) and Marnie (1964).

${ }^{28}$ Juan Luis Buñuel, Good Films..., pp.15-16.

${ }^{29}$ For recent examples see Rob Stone and Julián Gutiérrez-Albilla, A Companion to Luis Buñuel (Chichester: Wiley-Blackwell, 2013), and the Special Issue on Luis Buñuel of the Bulletin of Spanish Studies, 93:4, 2016.

${ }^{30}$ Douglas Cunningham, "IIt's all there, it's no dream": Vertigo and the Redemptive Pleasures of the Cinephilic Pilgrimage' Screen, 49:2 (Summer 2008), 123-141 (p. 124). 
'posthuman' age, as for Mexican and international film audiences in the early 1950s. In the context of our contemporary anxiety about biological origins, the screened projection of posttruth politics, pornography, and rising internet misogyny, this erotic fantasy directed by a man who didn't like filming sex scenes is hilariously prescient. ${ }^{31}$ These three short minutes that tether Oliverio to his mother, to Raquel in her swimsuit, and to the virginal Albina (not to mention the sheep) not only provide a perfect illustration of the complex ties that bind catholicism with sex, and surrealist amour fou with bourgeois convention, they also provide an equally perfect illustration of the complex umbilical link that Kracauer perceives in our relationship to the screen; of the ties that bind our erotic and affective attraction to the screened body; and of the abiding attachment to the 'lost' object that fuels our cinephilia.

\footnotetext{
${ }^{31}$ See, for example, his comments on the original screenplay of Cela s'appelle... in José de la Colina and Tomás Pérez Turrent ed., Object of Desire: Conversations with Luis Buñuel, trans. by Paul Lenti (New York: Marsilio, 1992), 122.
} 